\title{
Cancer testis antigen expression in triple negative breast cancer: Candidate targets for cancer immunotherapy?
}

\author{
Wouter Hendrickx', Mariam Al-Muftah², Julie Decock²* \\ From 30th Annual Meeting and Associated Programs of the Society for Immunotherapy of Cancer (SITC 2015) \\ National Harbor, MD, USA. 4-8 November 2015
}

\section{Background}

Breast cancer is a major health concern in Qatar with a younger age at diagnosis and projections of $60 \%$ increase in new cases. Triple negative breast cancer (TNBC) is associated with advanced disease at diagnosis and poorer outcome, and can be subclassified into 6 gene-expressionbased subtypes. These patients don't benefit from endocrine or HER2-targeted therapy and represent $15-20 \%$ of cases mandating the need for novel treatments. Although immunotherapy has shown promising results in different cancers, there are only 2 clinical trials to date assessing adoptive cell immunotherapy in TNBC. Cancer testis antigens (CTA) could be good candidate targets as their expression is often up-regulated in malignant tissues, while it is restricted in the testis and absent or very low in other somatic tissues.

\section{Methods}

We mined the TCGA and NCBI GEO repositories for genomic data on CTA expression in TNBC and selected a panel of 15 CTAs for further investigation. Gene and protein expression was investigated in a series of 9 human TNBC cell lines, encompassing all subtypes.

\section{Results}

We found the gene expression of TSAG10, MAGEA5, PLAC1, and DKKL1 to be moderate/highly expressed in our cell lines and in both datasets, and are confirming this on protein level. We are establishing a biobank of DNA and RNA of Qatari breast cancer patients and will present gene expression data of CTAs in TNBC tumors.

${ }^{2}$ Qatar Biomedical Research Institute, Doha, Qatar

Full list of author information is available at the end of the article

\section{Conclusions}

Our preliminary findings suggest that TSAG10, MAGEA5, PLAC1 and DKKL1 could be good candidate targets for TNBC immunotherapy, and in particular could benefit Qatari breast cancer patients.

\section{Authors' details \\ ${ }^{1}$ Sidra Medical and Research Institute, Doha, Qatar. ${ }^{2}$ Qatar Biomedical} Research Institute, Doha, Qatar.

Published: 4 November 2015

doi:10.1186/2051-1426-3-S2-P381

Cite this article as: Hendrickx et al:: Cancer testis antigen expression in triple negative breast cancer: Candidate targets for cancer immunotherapy? Journal for ImmunoTherapy of Cancer 2015 3(Suppl 2): P381.
Submit your next manuscript to BioMed Central and take full advantage of:

- Convenient online submission

- Thorough peer review

- No space constraints or color figure charges

- Immediate publication on acceptance

- Inclusion in PubMed, CAS, Scopus and Google Scholar

- Research which is freely available for redistribution
() Biomed Central 